\title{
Evaluation of Breast Masses Using Mammography and Sonography as First Line Investigations
}

\author{
Kishor Taori, Suresh Dhakate, Jawahar Rathod, Anand Hatgaonkar, Amit Disawal, \\ Prasad Wavare, Vishal Bakare, Rakhi P. Puria \\ Department of Radiodiagnosis, Government Medical College, Nagpur, India \\ Email: kishortaori@gmail.com
}

Received February 1, 2013; revised March 5, 2013; accepted March 14, 2013

\begin{abstract}
Purpose: To study the specificity of mammography and ultrasonography separately and in combination for detection of breast masses (ultrasonography-mammography correlation); To study the investigations to evaluate various breast masses; To describe suitable indications, advantages and limitations of each technique compared with other available modalities; To study the mimics of breast masses; To have histopathology follow-up and retrospective evaluation with imaging findings to improve diagnostic skills in series of 166 patients complaining of breast mass. Material: The prospective clinical study was carried out in the department of Radiodiagnosis for a period of 2-year extending from December 2010 to December 2012 in female patients complaining of breast mass. Well informed written consent was obtained from them. Histopathology follow up was obtained from either biopsy or post operative tissue. USG machine: Philips HD 11 XE USG of the breasts and axillary region done in supine position in presence of female attendant; Mammography machine: Allengers machine with Agfa special mammography cassettes. Cranio caudal and MedioLateral Oblique views are taken in the presence of female attendant. MRI: PHILIPS 1.5 T machine; CT: SIEMENS duel slice CT machine. Results: Ultrasonography and mammography was done in most of the cases were sufficient to diagnose the lesion in most of the cases especially in benign breast masses. MRI and CT scan was used in special cases to know the extent of the lesions, in mimics of breast masses, bony extensions, primary muscular and bony lesions. Total 166 patients complaining of breast mass in one or both breasts were examined and evaluated with USG and mammography. The lesions were confirmed on histopathology (FNAC/biopsy). Out of 30 diagnosed malignancies two lesions were missed on mammography and four lesions were missed on ultrasonography. One of them was missed on both. For malignancies specificity of mammography is $93.3 \%$ and that of ultrasonography is $86.67 \%$. Combining both the modalities specificity is near $97 \%$. Out of total 92 abnormal breasts 12 were missed on USG and 20 were missed on mammography. Combining both the modalities only 2 lesions were missed and were diagnosed on histopathology alone. Overall specificity for USG in breast masses is $86.9 \%$ and for mammography it is $78.6 \%$. Combining both the modalities the specificity is $97.6 \%$. The " $p$ " value is obtained which is highly significant for combination of ultrasonography and mammography in comparison with any individual modality $(p=0.0059 \& p=0.0001$ respectively). Conclusion: Our study confirms the higher combined sensitivity rate for ultrasonography and mammography for detection of breast masses including malignancies. USG is useful in cystic lesions, ectasias, infections, pregnancy-lactation, and dense breast evaluation and for image guidance, whereas mammography is useful in detecting microcalcifications, spiculated masses for early detection of malignancies and for stereotactic biopsies. To suggest single modality, ultrasonography is better in younger population and BIRAD 1, $2 \& 3$ lesions. Whereas, mammography is better in older population and BIRAD 4 \& 5 lesions. However, sono-mammographic correlation is best in both.
\end{abstract}

Keywords: Breast Masses; Ultrasonography; Mammography; Mimics; Correlation

\section{Introduction}

Breast diseases are common in females. In developing countries like India, females are unaware of breast pathologies and are hesitant to reveal, hence they are detected usually in advanced stages.

Various benign breast lesions like fibroadenomas, simple cyst, breast abscess, galactocele, duct actasia, en- larged lymph nodes and different malignancies are common pathologies of female breast.

Breast cancer is most common cause of cancer death in women and overall fifth common cause of cancer deaths in the world [1]. Delay in the detection causes, malignancy to progress in advanced stage. Usually it comprises of inoperable masses, metastasis (bone, brain, 
lung) and eventually leads to mortality.

Albert Soloman (1913) for the first time, after the invention of $X$ rays, studied the breast under $X$ rays and suggested that $\mathrm{X}$ rays can be used for diagnostic purpose for breast pathologies [2]. Mammography was used primarily for early detection of malignancies in their curable stages, to decrease the malignancy related mortality. It is screening tool which is easily available, cheap and fairly accurate with minimal radiation to detect microcalcifications, speculated masses and small lymph nodes seen in malignancies. Incidence of breast cancer can be reduced by $30 \%$ by the routine mammographic screening of healthy women $[3,4]$.

In the history of USG in 1951 Wild and Reid [5] first developed equipment specially designed for breast scanning. Once limited for differentiating between solid and cystic lesions, breast ultrasound now proposes an attempt to characterize the breast nodules and to differentiate them as benign and malignant. Breast ultrasound has evolved as an indispensible problem solving tool in patients with dense breasts, post-radiation breasts, and women less than 35 years of age, pregnant and lactating patients.

In our study, an attempt was made to evaluate various breast masses using USG and mammography separately and in combination, to describe suitable indications, advantages and limitations of each technique compared with other available modalities and to differentiate the benign breast lesions from the malignant ones.

\section{Case Series}

\subsection{Materials and Methods}

\subsubsection{Patients}

The prospective clinical study was carried out in the department Radiodiagnosis for a period of 2 year extending from December 2010 to December 2012 in patients complaining of breast mass (156 females and 10 males). Well informed written consent was obtained from them. Histopathology follow up was obtained from either biopsy or post operative tissue.

USG machine: Philips HD 11 XE;

USG of the breasts and axillary region done in supine and lateral position in presence of female attendant;

Mammography machine: Allengers machine with AGFA mammography cassettes;

Cranio caudal and Medio-Lateral Oblique views are taken in the presence of female attendant.

MRI: PHILIPS 1.5 T machine;

CT: SIEMENS duel slice CT machine.

Inclusion criteria:

- All patients with clinically palpable breasts masses;

- USG proven solid breast masses or complex cystic lesions;
- No obvious breast mass on palpation but prominent axillary nodes;

- Females with clinical signs of redness over the breast area, nipple retraction, dryness, altered shape;

- $\mathrm{K} / \mathrm{c} / \mathrm{o}$ carcinoma breast with mastectomy done on one side;

- Family history of breast mass in first degree relative.

\subsubsection{Exclusion Criteria}

- Very large and very tender breast;

- Very apprehensive patient.

\subsubsection{Confirmation}

1) FNAC/Biopsy in doubtful cases, post operative follow up in operative cases.

2) In cases of simple cysts and galactocele no histopathology confirmation was done. Aspiration of cyst was done to confirm.

3) No histopathology done in cases of normal ultrasound findings and normal mammography in patients complaining of apparent mass felt on clinical examination. Such patients refused to give consent for invasive histopathology study after normal reports and they were labelled as normal. Hence sensitivity and positive predictive value could not be obtained.

Statistical analysis for comparison study was done and "p" value was obtained. The values of specificity, negative predictive value, accuracy for ultrasound and mammography in overall breast masses (also separately in malignant lesions) were obtained when used separately and in combination.

\subsection{Observation}

In this study total 166 patients (Table 1) complaining of breast mass in one or both breasts were examined clinically and evaluated with USG and mammography. The lesions were confirmed on histopathology (biopsy/tissue from post operative specimens/aspiration) as per individual case.

Seventy four out of total 166 patients were labelled normal and they were not followed up.

Total 92 patients were abnormal and categorised according to the pathology (Table 2).

\subsubsection{Fibroadenomas}

Clinically patients present with the history of freely movable lump in one or both breasts since few months to years, usually painless. Nearly one third of them (8 patients) had previous history of similar mass being operated in one or both breasts. Out of total 21 patients of fibroadenomas most of them were younger (Figure 1). On mammography fibroadenoma shows well marginated soft tissue density radio-opacity with or without typical 
Table 1. Number of patients in specific age group.

\begin{tabular}{cc}
\hline Age Group & Number of Patients \\
\hline $20-25$ & 10 \\
$26-30$ & 20 \\
$31-35$ & 30 \\
$36-40$ & 24 \\
$41-45$ & 26 \\
$46-50$ & 20 \\
$51-55$ & 16 \\
$56-60$ & 12 \\
$61 \&$ Above & 8 \\
\hline
\end{tabular}

Table 2. Number of various pathologies in breast.

\begin{tabular}{cc}
\hline Pathology & Number of Patients \\
\hline Breast Malignancies & 30 \\
Fibroadenomas & 21 \\
Simple Cyst & 8 \\
Galactocele & 2 \\
Duct Ectasia & 6 \\
Breast Abscess & 2 \\
Mastitis & 4 \\
Pectoralis Major Muscle Hemangioma & 1 \\
Chondrosarcoma of the Rib & 1 \\
Malignant Mesosthelioma & 1 \\
Breast Hydatid & 1 \\
Perimenopausal Fibrocystic Changes & 15 \\
Normal & 74 \\
\hline
\end{tabular}

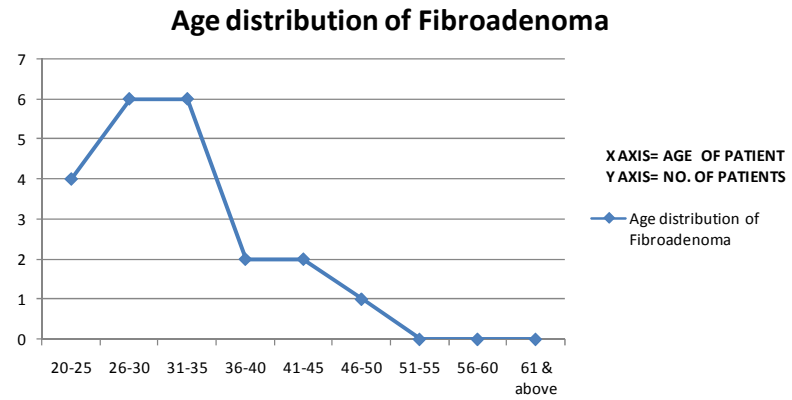

Figure 1. Shows number of fibroadenoma patients in specific age group.

benign type of circumferential, concentric calcifications (pop corn calcification) (Figure 2(a)). Many of the fibroadenoma do not show calcification (Figures 2(c) and

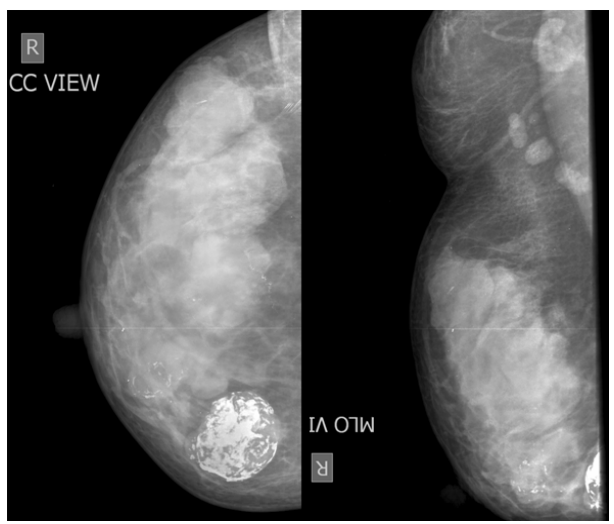

(a)

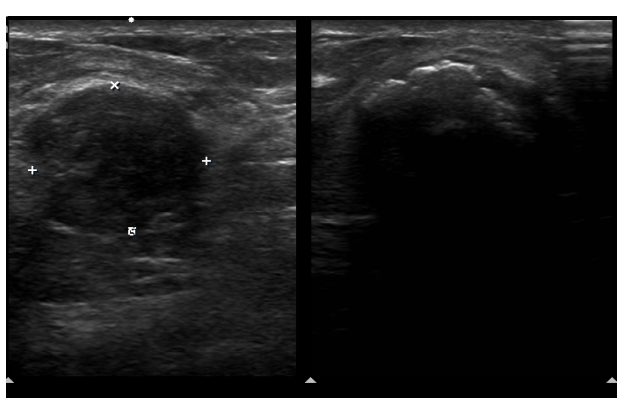

(b)

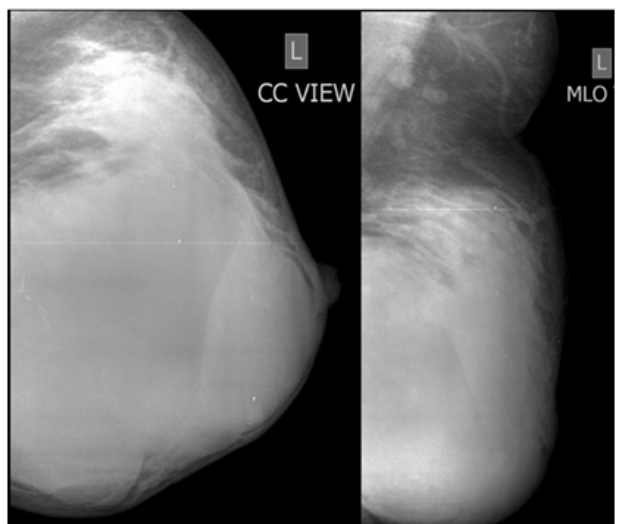

(c)

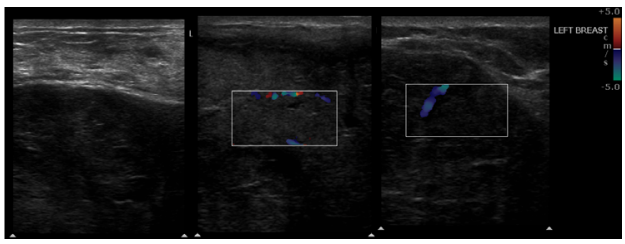

(d)

Figure 2. A case of bilateral fibroadenoma, showing a 45 years old female with complaints of lump in both breast since 3 months. Mammography (a) shows multiple fibroadenomas in varying degree of calcifications noted on right side and (b) sonography reveals well marginated rounded mass with homogeneous hypoechoic echotexture with post acoustic enhancement. On left side patient had (c) large giant fibroadenoma occupying almost whole of the breast with (d) sonography showing well defined hypoechoic lesion having vascularity within. 


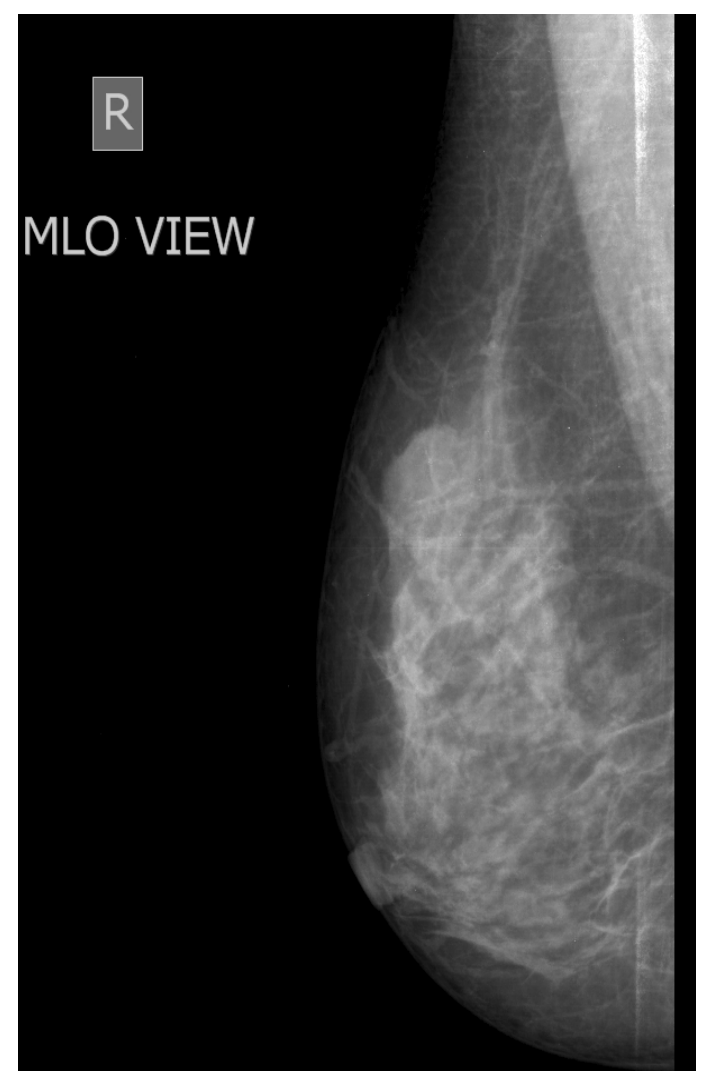

Figure 3. A case of fibroadenoma. Mammography shows well defined, smooth marginated rounded soft tissue density radioopacity with adjacent dense glandular tissue without architectural distortion or calcifications in a 28 years old female with complaints of mass in the right breast since 2 months. She was operated for fibroademona in the same breast 15 months back.

3). On ultrasonography well defined round to oval lesion, with homogeneous echotexture and width greater than depth (Figure 2(b)). Out of total 21 fibroadenomas, 1 was missed on ultrasound and 5 were missed on mammography but combining both, no fibroadenoma was missed.

\begin{tabular}{cccc}
\hline $\begin{array}{c}\text { Total number of } \\
\text { fibroadenoma } \\
\text { patients }\end{array}$ & $\begin{array}{c}\text { Detected by } \\
\text { only } \\
\text { mammography }\end{array}$ & $\begin{array}{c}\text { Detected by } \\
\text { only } \\
\text { ultrasound }\end{array}$ & $\begin{array}{c}\text { detected by } \\
\text { ultrasound }+ \\
\text { mammo }\end{array}$ \\
\hline 21 & $\begin{array}{c}17 \\
\text { Specificity: } \\
80.9 \%\end{array}$ & $\begin{array}{c}\text { Specificity: } \\
95 \%\end{array}$ & $\begin{array}{c}\text { Specificity: } \\
100 \%\end{array}$ \\
\hline
\end{tabular}

\subsubsection{Malignancies}

Malignant masses present clinically with lump in the breast, retracted nipple, pain \& bloody discharge, ulceration over the skin. Malignant lesions on mammography reveal irregular mass, spiculated or lobulated margins, focal asymmetry, lesion appears taller than wider, retracted nipple, calcification may be linear, branching, granular, clustered with surrounding architectural distortion (Figures 4-7).

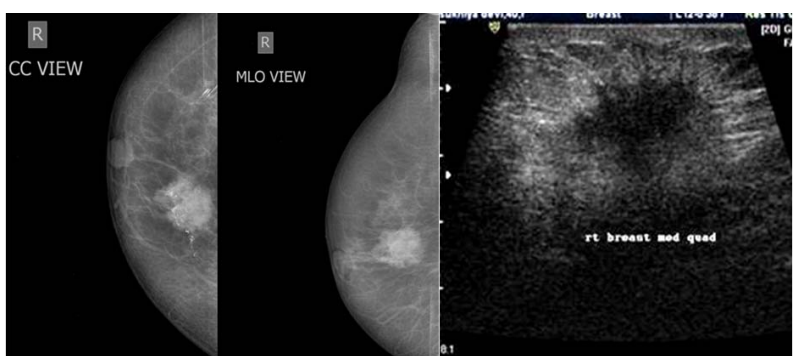

Figure 4. A case of ductal carcinoma breast. Irregular mass in superomedial quadrant of right breast with spiculated margin and retracted nipple in a 68 years old female with complaints of lump in the right breast since 1 month. On USG irregular hypoechoic mass with depth more than width. Lesions shows post acoustic shadowing.

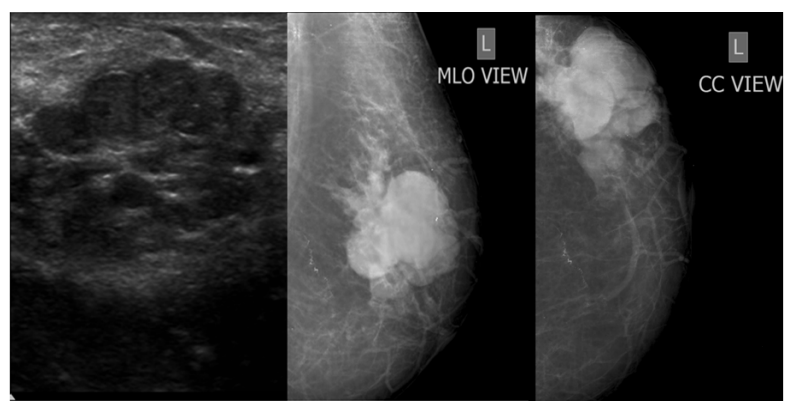

Figure 5. A case Anaplastic Large Cell NHL. E/o irregular lobulated mass lesion in superolateral quadrant of left breast in a 34 years old female with hard non tender mass in left breast since 3 years. Mass regressed on cytotoxic chemotherapy.

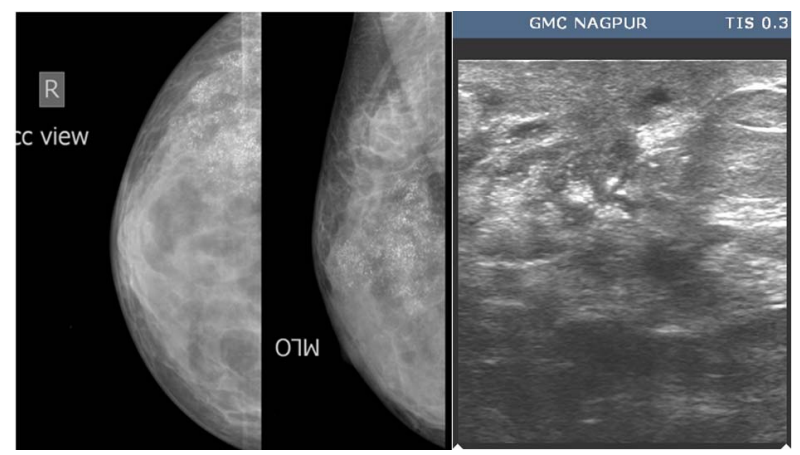

Figure 6. A case of ductal malignancy. Microcalcifications involving superolateral quadrant in a 51 years old female with lump in right breast since 6 months.

Out of 30 diagnosed malignancies:

- Chances of malignancies were higher in older patients complaining of breast mass than younger patients (Figure 8).

- Two lesions were missed on mammography and four lesions were missed on USG. One of them was missed on both.

For malignancies specificity of mammography is $93.3 \%$ and that of USG is $86.67 \%$. Combining both the modalities specificity is near $97 \%$. 


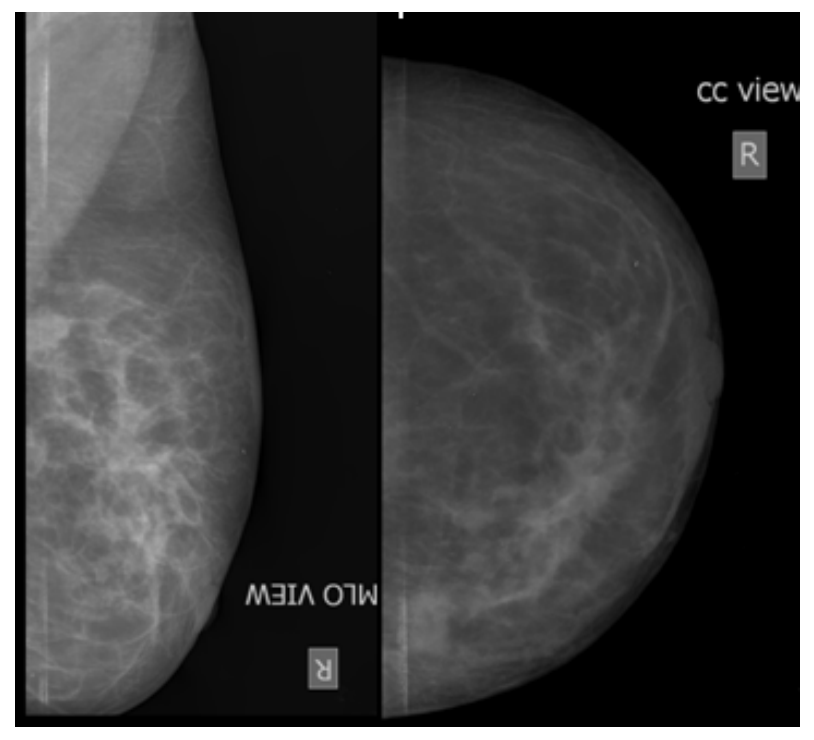

Figure 7. A case of ductal malignancy in a 36 years old female with complaints of gradually increasing lump in the right breast since 8 months. Mammography reveals focal asymmetry with surrounding architectural distortion involving superolateral quadrant of right breast.

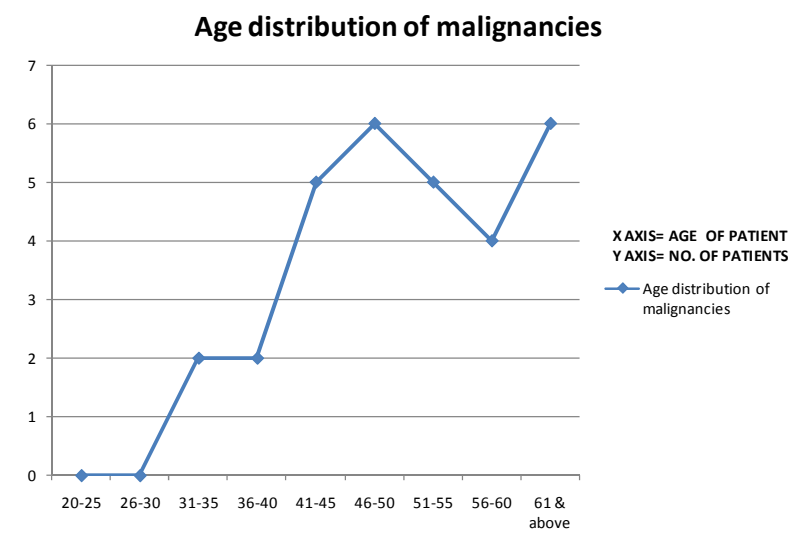

Figure 8. Graph showing age distribution of malignancies.

\begin{tabular}{cccc}
\hline $\begin{array}{c}\text { Total number of } \\
\text { malignancies }\end{array}$ & $\begin{array}{c}\text { Detected by only } \\
\text { mammography }\end{array}$ & $\begin{array}{c}\text { Detected by only } \\
\text { ultrasound }\end{array}$ & $\begin{array}{c}\text { Detected by } \\
\text { ultrasound + } \\
\text { mammo }\end{array}$ \\
\hline 30 & 28 Specificity: & 26 Specificity: & 29 Specificity: \\
& $93.3 \%$ & $86.67 \%$ & $97 \%$ \\
\hline
\end{tabular}

\subsubsection{Cystic Lesions}

Cystic lesions present clinically with lump in the breast. On Mammography cystic lesions appear well defined soft tissue density lesions and could not be differentiated from solid masses like fibroadenoma (Figures 9 and 10). On ultrasonography cystic lesiosns can easily diagnosed. For cystic lesions like simple cysts, multiple cysts in perimenopausal fibrocystic changes (Figure 10), galactocele (Figure 11) and in duct ectasia (Figure 12) ultrasonography is far better than mammography.

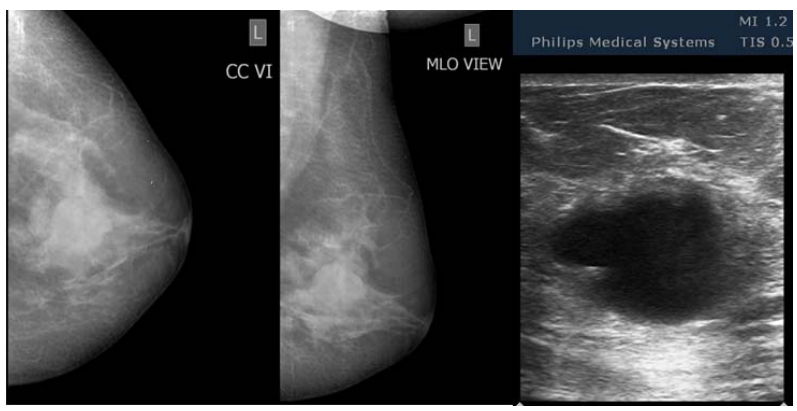

Figure 9. A case of simple cyst. Mammography reveals relatively well marginated, soft tissue density lesion involving subareolar region in a $\mathbf{3 3}$ years old female with complaints of lump in the left breast since 6 months. Well circumscribed cyst noted on sonography. Mammography cannot differentiate cyst from solid mass (compare with Figures 3 and 4) but sonography can easily differentiate.

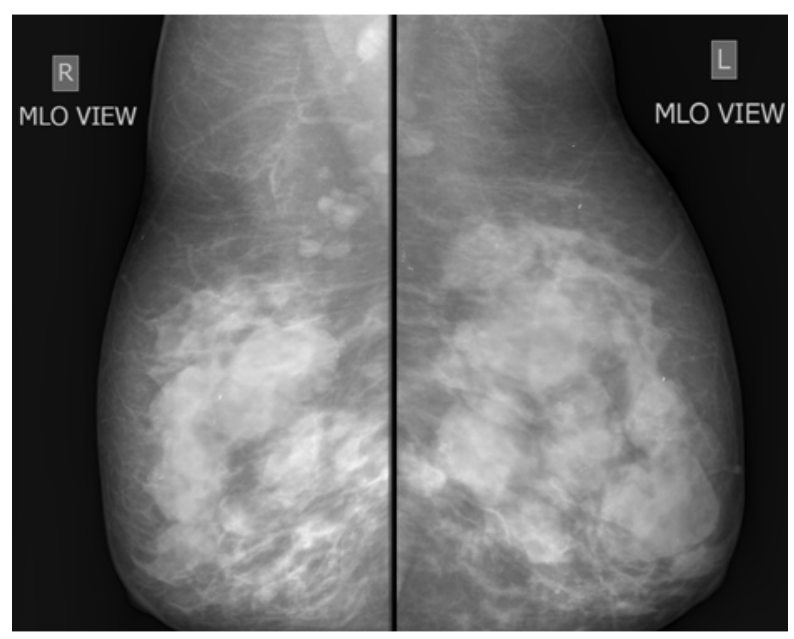

(a)

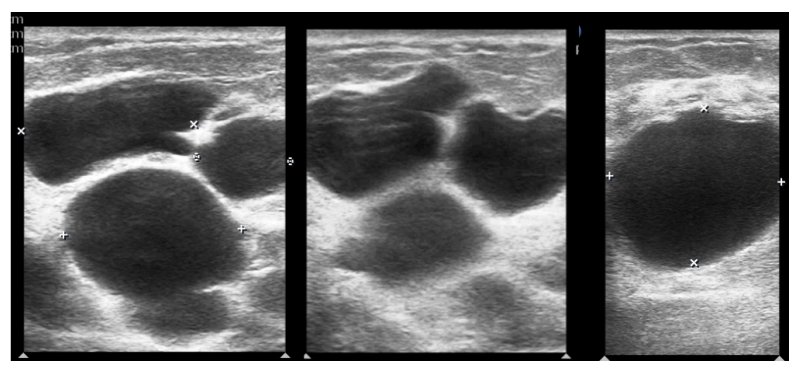

(b)

Figure 10. A case of bilateral fibro cystic changes, showing a 40 years old female with complaints of lump in both breasts since 4 months. Mammography (a) reveals bilateral multiple soft tissue density lesions without obvious architectural distortion. Sonography (b) revealed multiple cystic lesions (except for calcifications Figures 2(a) and 10(a) are comparable).

All the patients with duct ectasia were above 40 years and had complaints of turbid discharge from the nipple. Mammograms in most of the duct ectasia patients were labelled as normal with mixed parenchymal pattern (P1/ 


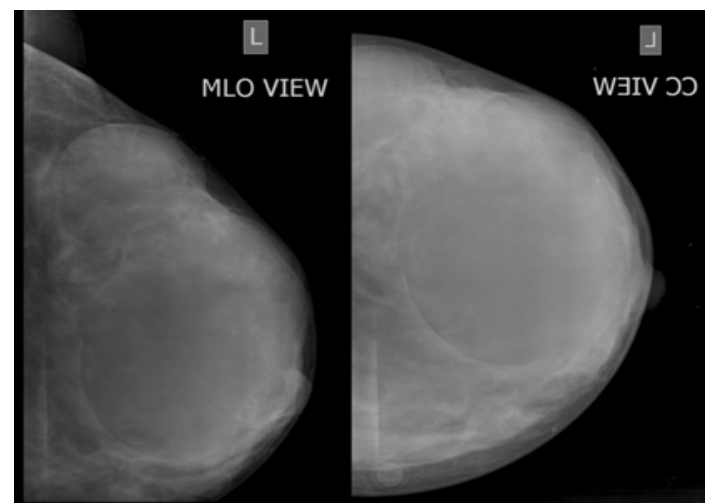

Figure 11. A case of galactocele, showing a 28 years old female with complaints of lump in the left breast. Mammography revealed well defined rounded lesions with relatively radiolucent lesion with lucent halo around. Sonography revealed well defined rounded cyctic lesion with internal echos within (not shown in figure).

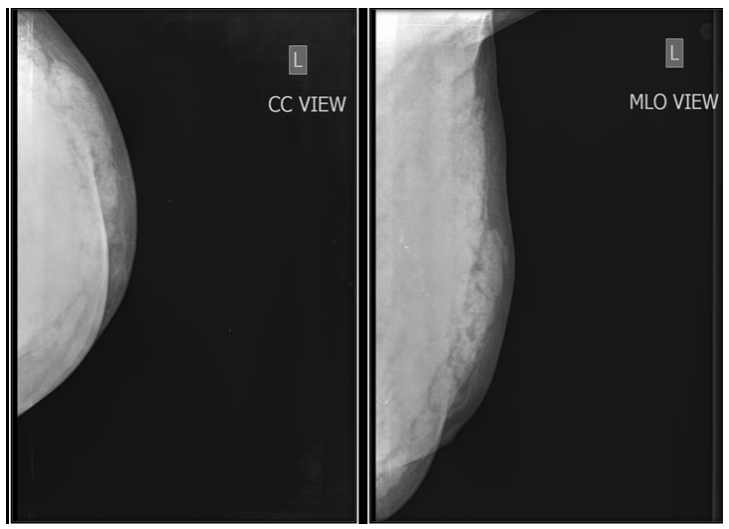

(a)

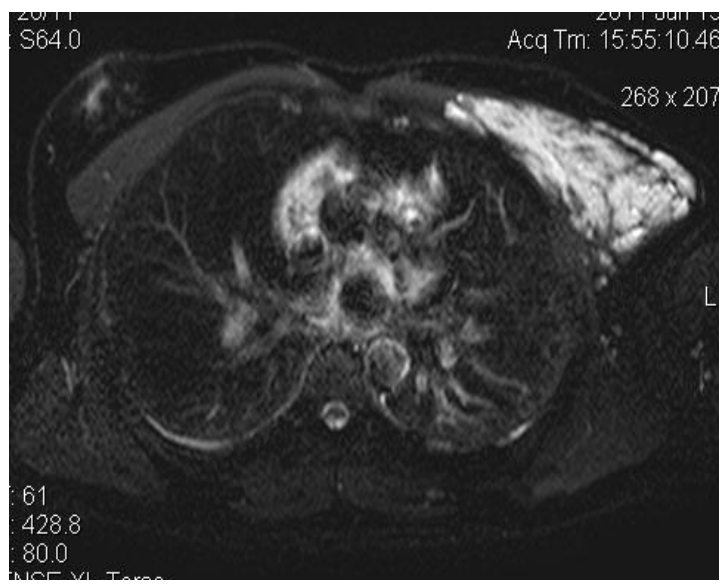

(b)

Figure 12. A case of pectoralis major muscle hemangioma. Well defined radio-opacity involving supero-lateral and inferolateral quadrant of left breast with lobulated margins not separately visualized from pectoral muscles in a 45 years old male patient. Sonography revealed numerous small compressible cystic spaces within the mass (not shown); (b) fat suppressed T2 W sequence showed typical hemangioma involving left pectoralis major muscle.
ACR 2 pattern) except in one patient in fatty breast was given. Ultrasonography proved to be problem solving in all the cases of duct ectasia.

Out of total 15 perimenopausal fibrocystic changes patients 11 were correctly diagnosed on mammography (specificity $73.3 \%$ ) but all the lesions could be correctly picked up on ultrasonography (specificity 100\%) in appropriate clinical setting.

Simple cysts on ultrasound were aspirated and were not subjected to biopsy, only one of them needed total of three aspirations.

\begin{tabular}{ccc}
\hline & Ultrasound & Mammography \\
\hline $\begin{array}{c}\text { Galactocele } \\
\text { (2 cases) }\end{array}$ & $\begin{array}{c}\text { Both diagnosed } \\
\text { correctly }\end{array}$ & 1 Correct diagnosis \\
$\begin{array}{c}\text { Duct ectasia } \\
\text { (6 cases) }\end{array}$ & All 6 diagnosed on USG & $\begin{array}{c}\text { Without history, } \\
\text { Inconclusive in 5 cases }\end{array}$ \\
$\begin{array}{c}\text { Simple cyst } \\
\text { (8 cases) }\end{array}$ & All diagnosed by USG & Inconclusive in all cases \\
\hline
\end{tabular}

Mammography was tried but in view of patients anxiety the procedure was later denied in 4 patients, 1 of breast abscess and 3 of mastitis due to relatively painful and tender breasts. Ultrasonography was the only investigation helpful in these cases. Hence ultrasound proved to be better than mammography in inflammatory conditions and many times it is the only investigation done in these cases.

\subsubsection{Mimics of the Breast Masses}

Other lesions which are extrabreast in origin can also present as swelling or mass in the breast. Our study includes 4 such cases involving pectoralis major muscle hemangioma (Figure 12), chondrosarcoma of the rib (Figure 13), breast hydatid and malignant pleural mesothelioma. Most of these masses were hard, tense or flat hence mammography could only be done in soft mass like pectoralis major muscle hemangioma. In most of these cases cross sectional imaging was necessary to know the extent of the lesion, adjacent bone and pleura involvement, vascularity and ultimately operability of the lesion. Post operative histopathology was done in hemangioma and breast hydatid whereas biopsy was done for confirm diagnosis in chondrosarcoma and malignant pleural mesothelioma.

Out of total 92 abnormal breasts 12 were missed on USG and 20 were missed on mammography. Combining both the modalities only 2 lesions were missed and were diagnosed on histopathology alone.

\begin{tabular}{cccc}
\hline $\begin{array}{c}\text { Total } \\
\text { abnormal } \\
\text { breasts }\end{array}$ & $\begin{array}{c}\text { Diagnosed } \\
\text { by only } \\
\text { mammography }\end{array}$ & $\begin{array}{c}\text { Diagnosed } \\
\text { by only } \\
\text { ultrasound }\end{array}$ & $\begin{array}{c}\text { Diagnosed by } \\
\text { combining both } \\
\text { sono + mammo }\end{array}$ \\
\hline 92 & 72 & 80 & 90 \\
\hline
\end{tabular}




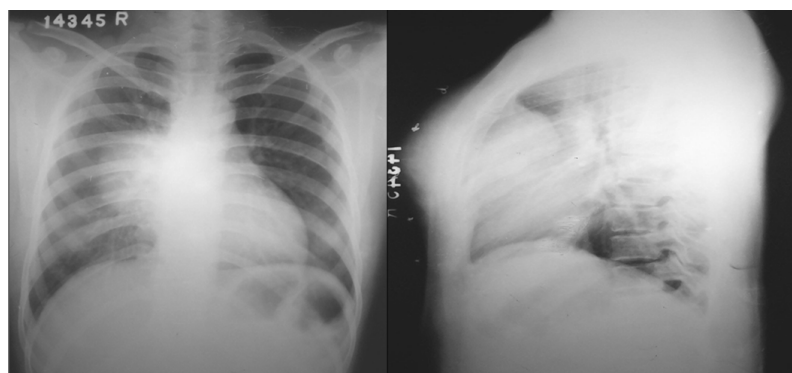

(a)

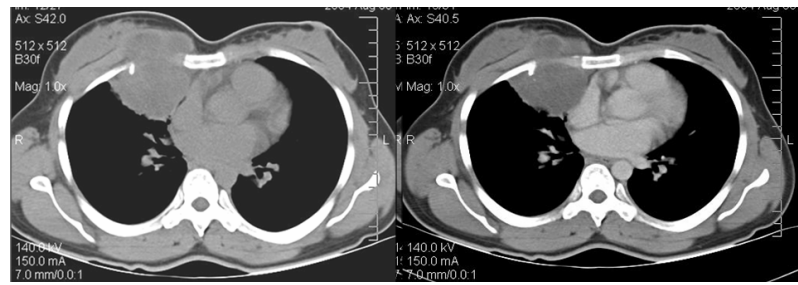

(b)

Figure 13. A case of chondrosarcoma of the rib. (a) Radiograph chest PA view reveals well defined homogenous radio-opacity in right midzone with broad base to mediastinum \& silhoutting right heart border. Lateral view reveals anterior mediastinum mass with soft tissue radio-opacity seen extending anterior to sternum; (b) Pre and post contrast CT thorax Mediastinal window reveals relatively non enhancing mass lesion involving right anterior chest wall with rib destruction and intrathoracic extension.

Overall specificity for USG in breast masses is $86.9 \%$ and for mammography it is $78.6 \%$. Combining both the modalities the efficiency is $97.6 \%$.

\begin{tabular}{ccc}
\hline $\begin{array}{c}\text { Overall diagnostic } \\
\text { potential for }\end{array}$ & $\begin{array}{c}\text { Overall } \\
\text { diagnostic } \\
\text { potential for } \\
\text { mammography in } \\
\text { breast masses }\end{array}$ & $\begin{array}{c}\text { Diagnostic } \\
\text { breast massential for }\end{array}$ \\
& ultrasound +mammography \\
\hline Specificity: $78.2 \%$ & Specificity: $86.9 \%$ & Specificity: $97.8 \%$ \\
Accuracy: $87.9 \%$ & Accuracy: $92.7 \%$ & Accuracy: $98.8 \%$ \\
P(-)ve: $78.2 \%$ & P(-)ve: $86 \%$ & P(-)ve: $97.4 \%$ \\
\hline
\end{tabular}

\subsection{Statistical Analysis and Significance}

> Comparing diagnostic accuracy of only mammogramphy with mammography plus ultrasonography in overall breast masses the $\mathrm{p}$ value is highly significant $(\mathrm{p}=$ 0.0001).

$>$ Comparing diagnostic accuracy of only ultrasonography with mammography plus ultrasonography in overall breast masses the $\mathrm{p}$ value is highly significant $(\mathrm{p}=0.0059)$.

$>$ Comparing only mammography with only ultrasonography in overall breast masses the $p$ value is $(p=$ 0.1189 ) not significant.

\subsubsection{Follow Up}

In breast malignancies modified radical mastectomy was done with single mortality up to the follow up of 6 months. One of the patient with anaplastic large cell non hodgkin's lymphoma, chemotherapy (cyclophosphamide, doxorubicin, vincrinstine and prednisone) was the treatment started. Lumpectomy was done in most of the cases of fibroademona with few of them needed simple mastectomy. Only follow up mammograms was advised to the patients with perimenopausal fibrocystic changes. In case of duct ectasia only follow up mammograms were advised. Therapeutic aspiration was done in both cases of galactocele.

Mammography

\begin{tabular}{|c|c|}
\hline Advantages & Limitations \\
\hline $\begin{array}{l}\text { Better detection of } \\
\text { microcalcification }\end{array}$ & $\begin{array}{l}\text { Solid and cystic masses not } \\
\text { better differentiated }\end{array}$ \\
\hline $\begin{array}{l}\text { Better in detection of } \\
\text { spiculated masses }\end{array}$ & $\begin{array}{c}\text { Not done in pregnancy and } \\
\text { lactation }\end{array}$ \\
\hline $\begin{array}{l}\text { Multiple lesions with spacial } \\
\text { relation with each other can be } \\
\text { better made out }\end{array}$ & $\begin{array}{l}\text { Not done in very painful } \\
\text { tender breast }\end{array}$ \\
\hline \multirow[t]{4}{*}{ Stereotactic biopsy can be done } & $\begin{array}{l}\text { Sensitivity decline in dense } \\
\text { breast \& breast infections }\end{array}$ \\
\hline & $\begin{array}{l}\text { Not done in Flat masses and } \\
\text { mimics of breast masses } \\
\text { (bony or pleural lesions) }\end{array}$ \\
\hline & $\begin{array}{c}\text { Complete visualization of the } \\
\text { breast is not possible in any } \\
\text { single view }\end{array}$ \\
\hline & $\begin{array}{l}\text { Very large breasts could not be } \\
\text { evaluated adequately }\end{array}$ \\
\hline \multicolumn{2}{|l|}{ Ultrasonography } \\
\hline Advantages & Limitations \\
\hline $\begin{array}{c}\text { Better in detection of cystic } \\
\text { lesion and intracystic } \\
\text { contents (echos,debris, septae \& } \\
\text { daughter cysts etc.) }\end{array}$ & Microcalcifications can be missed \\
\hline $\begin{array}{l}\text { Better in infective pathologies } \\
\text { and tender breast }\end{array}$ & Fat and air can obscure the lesion \\
\hline $\begin{array}{c}\text { Dense breasts are evaluated } \\
\text { better }\end{array}$ & $\begin{array}{l}\text { Relatively well defined malignant } \\
\text { masses can be labelled as benign }\end{array}$ \\
\hline $\begin{array}{l}\text { No radiation exposure, better } \\
\text { in pregnancy \& lactation }\end{array}$ & $\begin{array}{l}\text { Sensitivity depends on the } \\
\text { operator }\end{array}$ \\
\hline $\begin{array}{l}\text { Vascularity can be } \\
\text { commented }\end{array}$ & $\begin{array}{l}\text { Isoechoic and multicentric } \\
\text { lesions can be missed. }\end{array}$ \\
\hline \multicolumn{2}{|l|}{$\begin{array}{l}\text { It is real time and whole } \\
\text { breast region can be } \\
\text { evaluated even in large breasts. }\end{array}$} \\
\hline $\begin{array}{c}\text { Flat bony lesions and mimics of } \\
\text { the breast masses can be } \\
\text { evaluated better }\end{array}$ & \\
\hline
\end{tabular}


MRI is important in relatively difficult cases to differentiate between malignant and benign lesions, degree of invasion in to the surrounding soft tissue and perfusion pattern and hence is more reliable. To determine multifocality, to differentiate scar tissue and recurrent cancer, to evaluate breast implants. It is costly and unaffordable in many patients.

CT scan is important in bony lesions, to determine bony destruction and intra-thoracic extension and in patients who cannot afford costly investigations like MRI.

\section{Discussion}

Breast masses are common in female and amongst all the breast masses, malignant masses are the most feared [6, 7]. Breast cancer is the commonest cause of cancer mortality in females [1] whereas breast cancer in men accounts for only $0.7 \%$ of all breast cancers [8].

Patients with palpable breast lesion commonly present for radiology evaluation. Various imaging techniques like mammography, ultrasonography, MRI, scintimammography and PET are now available [9]. Mammography is primary method of detection and diagnosis of breast disease with sensitivity of $85 \%-95 \%$ [10]. The specific mammographic features of the breast mass help in diagnosis. Benign lesions show round to oval shape, well defined margins, few lobulations, low soft tissue density and fat containing lesions. Malignant lesions are high soft tissue density, irregular margins, multiple lobulations and spiculations with or without microcalcifications [11].

Mammography in breast mass can be used to look for microcalcifications and architectural distortion, speculated margins and hence to determine the potential malignant nature of the lesion also to screen for occult disease in the surrounding tissue [12-14]. Mammography proved to be an effective diagnostic tool for defining the benign and malignant characteristics of palpable breast mass [15].

Mammography is nearly $87 \%$ accurate in detecting cancer [16-21], its specificity is $88 \%$ and its positive predictive value may be as high as $22 \%$ [20]. But the false negative findings in mammography in evaluation of palpable breast mass is high, estimated between $4 \%$ \& $12 \%$ [22,23].

Hence many of the times, other modalities are needed to compliment the primary diagnosis given on mammography.

Ultrasonography is perfect adjunct to the mammography since both the modalities are easily available, relatively cheaper and can take relatively less time. Initially ultrasonography was only used to differentiate solid from cystic masses. Ultrasonography effectively differentiates solid lesions from cysts which account for nearly $25 \%$ of breast lesions [18]. Now it can be used to evaluate dense breasts usually below 35 years of age. In the breasts where solid lesions and cysts are obscured by mammography due to dense fibroglandular tissue, ultrasonography help in diagnosis and to decrease the number of surgical biopsies [22,23]. It is necessary to evaluate the complex cysts or cyst which need repeated aspiration since they can harbor malignancy [18]. Ultrasonography can be used to differentiate benign from malignant lesions with negative predictive value of $99.5 \%$, specificity of $67.8 \%$ and overall accuracy of $72.9 \%$ (Stavros et al.) [24]. The specific sonographic features determining the benign nature of the lesion include intense hyperechogenicity, ellipsoid shape, gentle lobulations, thin echogenic pseudocapsule and less than four gentle lobulations. Malignant nature of the lesion is given by spiculations, angular margins, shadowing, microlobulations and microcalcifications [2426].

Though a definitive diagnosis is possible with noninvasive imaging procedures, for most lesions histopathology or cytology (biopsy/FNAC) are proven tools and essential for obtaining confirm diagnosis [10,27-29].

It is important to be aware about the other extrabreast lesions which can present with palpable breast mass. Chest wall lesions, muscular and pleural lesions, bony masses, hydatid disease can present clinically with breast swelling. Appropriate cross sectional imaging can help.

Finally though mammography and ultrasonography have their own advantages and limitations. No single investigation is $100 \%$ accurate but combination of mammography and ultrasonography can yield near $100 \%$ results [30].

\section{Conclusions}

Our study confirms the higher combined specificity for ultrasonography and mammography for detection of breast masses including malignancies. USG is better in cystic lesions, ectasias, infections and inflammatory conditions, pregnancy-lactation, dense breast evaluation and real time image guidance, whereas mammography is better in detecting microcalcifications, spiculated masses for early detection of occult malignancies and for stereotactic biopsies.

Ultrasonography and mammography cannot replace each other but to suggest single modality, ultrasonography is better in younger population and BIRAD 1, $2 \& 3$ lesions. Whereas, mammography is better in older population and BIRAD 4 \& 5 lesions. However, sono-mammographic correlation is best in both.

Extrabreast lesions can mimic breast mass, its awareness and careful cross sectional imaging can be problem solving. Mammography do not help much in these cases. 


\section{REFERENCES}

[1] World Health Organization, "Fact Sheet No. 297: Cancer," 2006.

[2] R. H. Gold, "The Evolution of Mammography," $R a-$ diologic Clinics of North America, Vol. 30, No. 1, 1992, pp. 1-19.

[3] K. T. Morris, J. T. Vetto, J. K. Petty, S. S. Lum, W. A. Schmidt, S. Toth-Fejel, et al., "A New Score for the Evaluation of Palpable Breast Masses in Women under Age 40," American Journal of Surgery, Vol. 184, No. 4, 2002, pp. 346-347. doi:10.1016/S0002-9610(02)00947-9

[4] W. A. Berg, L. Gutierrez, M. S. Ness Aiver, W. B. Carter, M. Bhargavan, R. S. Lewis and O. B. Ioffe, "Diagnostic Accuracy of Mammography, Clinical Examination, US, and MR Imaging in Preoperative Assessment of Breast Cancer," Radiology, Vol. 233, No. 3, 2004, pp. 830-849.

[5] J. J. Wild and J. M. Reid, "Further Pilot Echographic Studies on the Histologic Structure of Tumors of the Living Intact Human Breast," American Journal of Pathology, Vol. 28, No. 5, 1952, pp. 839-886.

[6] D. Clarke, N. Sudhakaran and C. A. Gateley, "Replace Fine Needle Aspiration Cytology with Automated Core Biopsy in the Triple Assessment of Breast Cancer," Annals of The Royal College of Surgeons of England, Vol. 83, No. 2, 2001, pp. 110-112.

[7] J. M. Schoonjans and R. F. Brem, "Fourteen-Gauge Ultrasonographically Guided Large-Core Needle Biopsy of Breast Masses," Journal of Ultrasound in Medicine, Vol. 20, No. 9, 2001, pp. 967-972.

[8] S. H. Giordano, "A Review of the Diagnosis and Management of Male Breast Cancer," Oncologist, Vol. 10, No. 7, 2005, pp. 471-479. doi:10.1634/theoncologist.10-7-471

[9] Noninvasive Diagnostic Tests for Breast Abnormalities: Update of a 2006 Review. www.effectivehealthcare.ahrq.gov/reports/final.cfm

[10] K. L. Chakraborti, P. Bahl, M. Sahoo, S. K. Ganguly and C. Oberoi, "Magentic Resonance Imaging of Breast Masses: Comparison with Mammography," Indian Journal of Radiology and Imaging, Vol. 15, No. 3, 2005, pp. 381387 doi:10.4103/0971-3026.29160

[11] W. P. Evans, "Breast Masses, Appropriate Evaluation," RCNA, Vol. 33, No. 6, 1995, pp. 1085-1108.

[12] K. Kerlikowske, R. Smith-Bindman, B. M. Ljung and D. Grady, "Evaluation of Abnormal Mammography Results and Palpable Breast Abnormalities," Annals of Internal Medicine, Vol. 139, No. 4, 2003, pp. 274-284.

[13] M. Kumle, E. Weiderpass, T. Braaten, I. Persson, H. O. Adami and E. Lund, "Use of Oral Contraceptives and Breast Cancer Risk: The Norwegian-Swedish Women's Lifestyle and Health Cohort Study," Cancer Epidemiology, Biomarkers \& Prevention, Vol. 11, No. 11, 2002, pp. 1375-1381.

[14] M. K. Shetty, Y. P. Shah and R. S. Sharman, "Prospective Evaluation of the Value of Combined Mammographic and Sonographic Assessment in Patients with Palpable Abnormalities of the Breast," Journal of Ultrasound in Medicine, Vol. 22, No. 3, 2003, pp. 263-268.
[15] G. Gurung, R. K. Ghimire and B. Lohani, "Mammographic Evaluation of Palpable Breast Masses with Pathological Correlation: A Tertiary Care Centre Study in Nepal," Journal of Institute of Medicine, Vol. 32, No. 2, 2010, pp. 21-25

[16] J. R. Osuch, M. J. Reeves, D. R. Pathak and T. Kinchelow, "BREASTAID: Clinical Results from Early Development of a Clinical Decision Rule for Palpable Solid Breast Masses," Annals of Surgery, Vol. 238, No. 5, 2003, pp. 728-737. doi:10.1097/01.sla.0000094446.78844.ae

[17] H. A. Moss, P. D. Britton, C. D. Flower, A. H. Freeman, D. J. Lomas and R. M. Warren, "How Reliable Is Modern Breast Imaging in Differentiating Benign from Malignant Breast Lesions in the Symptomatic Population?" Clinical Radiology, Vol. 54, No. 10, 1999, pp. 676-682. doi:10.1016/S0009-9260(99)91090-5

[18] W. A. Berg, C. I. Campassi and O. B. Ioffe, "Cystic Lesions of the Breast: Sonographic-Pathologic Correlation," Radiology, Vol. 227, No. 1, 2003, pp. 183-191. doi:10.1148/radiol.2272020660

[19] T. M. Kolb, J. Lichy and J. H. Newhouse, "Comparison of the Performance of Screening Mammography, Physical Examination, and Breast US and Evaluation of Factors that Influence Them: An Analysis of 27,825 Patient Evaluations," Radiology, Vol. 225, No. 1, 2002, pp. 165-175. doi:10.1148/radiol.2251011667

[20] W. E. Barlow, C. D. Lehman, Y. Zheng, R. Ballard-Barbash, B. C. Yankaskas, G. R. Cutter, et al., "Performance of Diagnostic Mammography for Women with Signs or Symptoms of Breast Cancer," Journal of the National Cancer Institute, Vol. 94, No. 15, 2002, pp. 1151-1159. doi:10.1093/jnci/94.15.1151

[21] D. Lister, A. J. Evans, H. C. Burrell, R. W. Blamey, A. R. Wilson, S. E. Pinder, et al., "The Accuracy of Breast U1trasound in the Evaluation of Clinically Benign Discrete, Symptomatic Breast Lumps," Clinical Radiology, Vol. 53, No. 10, 1998, pp. 490-492. doi:10.1016/S0009-9260(98)80167-0

[22] M. A. Dennis, S. H. Parker, A. J. Klaus, A. T. Stavros, T. I. Kaske and S. B. Clark, "Breast Biopsy Avoidance: The Value of Normal Mammograms and Normal Sonograms in the Setting of a Palpable Lump," Radiology, Vol. 219, No. 1, 2001, pp. 186-191.

[23] S. P. Weinstein, E. F. Conant, S. G. Orel, J. A. Zuckerman, B. Czerniecki and T. J. Lawton, "Retrospective Review of Palpable Breast Lesions after Negative Mammography and Ultrasonography," Journal of Women's Imaging, Vol. 2, 2000, pp. 15-18

[24] A. T. Stavros, D. Thickman, C. L. Rapp, M. A. Dennis, S. H. Parker and G. A. Sisney, "Solid Breast Nodules: Use of Ultrasonography to Distinguish between Benign and Malignant Lesions,” Radiology, Vol. 196, No. 1, 1995, pp. 123-134.

[25] E. Ueno, E. Tohno and K. Itoh, "Classification and Diagnostic Criteria in Breast Echography," Journal of Medical Ultrasonics, Vol. 13, No. 1, 1986, pp. 19-31.

[26] P. Skaane and K. Engedal, "Analysis of Sonographic Features in the Differentiation of Fibroadenoma and Invasive Ductal carcinoma," American Journal of Roent- 
genology, Vol. 170, No. 1, 1998, pp. 109-114. doi:10.2214/ajr.170.1.9423610

[27] W. H. Hindle, P. A. Payne and E. Y. Pan, "The Use of Fine-Needle Aspiration in the Evaluation of Persistent Palpable Dominant Breast Masses," American Journal of Obstetrics \& Gynecology, Vol. 168, No. 6, 1993, pp. 1814-1819.

[28] H. C. Lee, P. J. Ooi, W. T. Poh and C. Y. Wong, "Impact of Inadequate Fine-Needle Aspiration Cytology on Outcome of Patients with Palpable Breast Lesions," Australian and New Zealand Journal of Surgery, Vol. 70, No. 9, 2000, pp. 656-659. doi:10.1046/j.1440-1622.2000.01920.x

[29] H. Khatun, Tareak-Al-Nasir, S. Enam, M. Hussain and M. Begum, "Correlation of Fine Needle Aspiration Cytology and Its Histopathology in Diagnosis of Breast Lumps," Bangladesh Medical Research Council Bulletin, Vol. 28, No. 2, 2002, pp. 77-81.

[30] S. N. Prasad and D. Houserkova, "A Comparison of Mammography and Ultraultrasonography in the Evaluation of Breast Masses," Biomedical Papers of the Medical Faculty of the University Palacky, Olomouc, Czech Republic, Vol. 151, No. 2, 2007, pp. 315-322. doi:10.5507/bp.2007.054 